Proc. Estonian Acad. Sci. Geol., 2000, 49, 3, 163-176

\title{
VOLCANIC INTERBEDS IN THE SILURIAN OF THE SOUTHWESTERN PART OF THE EAST EUROPEAN PLATFORM
}

\author{
Tarmo KIIPLI ${ }^{\mathrm{a}}$, Petro D. TSEGELNJUK ${ }^{\mathrm{b}}$, and Toivo KALLASTE ${ }^{\mathrm{c}}$
}

${ }^{a}$ Mining Institute of Tallinn Technical University, Kopli 82, 10412 Tallinn, Estonia

b Institute of Geological Sciences, Academy of Sciences, Ukraine, Chkalova 55b, 252054 Kyiv, Ukraine

c Institute of Geology, Tallinn Technical University, Estonia pst. 7, 10143 Tallinn, Estonia; ptrgi@teleport.ee

Received 11 January 2000, in revised form 10 April 2000

\begin{abstract}
Sixteen samples of altered volcanic ash interbeds from the Silurian of Volynia, Podolia, and Moldova were investigated by $\mathrm{X}$-ray fluorescence and X-ray diffraction analyses. Two associations of main minerals were established: (1) ordered illite and (2) illite-smectite with $\mathrm{K}$-sanidine. The $\mathrm{Nb} / \mathrm{Y}$ and $\mathrm{Zr} / \mathrm{TiO}_{2}$ ratios indicate rhyodacite-dacite and trachyandesite as the source magmas. The relative similarity of trace element composition in these volcanic beds point to a common source area of Late Silurian eruptions.
\end{abstract}

Key words: Silurian, volcanism, K-bentonite, metabentonite, Volynia, Podolia, Moldova.

\section{INTRODUCTION}

Excellent fossil-rich Silurian sections of Podolia (Ukraine) are well known along the Dniester River banks and its tributaries. Only a few borehole sections in the Middle Dniester area have previously been used for correlations. More recently, numerous boreholes drilled in the Volyno-Podolian and pre-Carpathian area have substantially promoted the study of Silurian deposits. Abundant new data have been obtained on fossils (brachiopods, graptolites, chitinozoans and others) and facies variability of the Silurian over the whole southwestern part of the East European Platform.

Volcanic beds occur as clay bands with a thickness from $1 \mathrm{~mm}$ to $1.45 \mathrm{~m}$ in predominantly carbonate sections and can be used as good time markers for the 
correlation of sections. Volcanic origin of these clay beds has been proved by findings of broken and euhedral phenocrystals of biotite, quartz, apatite, and zircon in the coarse fraction (Huff et al. 2000). Sometimes the beds are closely spaced vertically, which may cause problems in correlations. In such cases the knowledge of the chemical characteristics of the beds might prove useful. The present work is an attempt to investigate the trace elements in volcanic beds from the southwestern part of the East European Platform with the aim of assessing the prospect of using trace elements for the correlation of ash beds in the region. Besides facilitating the correlation of sections, the information about the content of immobile trace elements in volcanic beds can provide an insight into the Silurian volcanism in the surrounding areas. This study was carried out in the framework of the research project on Silurian volcanic interbeds of Estonia with the aim to obtain comparative data on the composition and areal distribution of volcanic material.

The volcanic origin of clay interbeds in Volynia and Podolia was first recognized by Savchenko \& Krandievskij (1967). Tsegelnjuk (1980a, 1980b, 1983) and Tsegelnjuk et al. (1983) have provided the first detailed report on the stratigraphic distribution of volcanic beds in the region. More recently the clay mineralogy and trace element chemistry of outcrop samples were studied by Huff et al. (2000). Clay-rich interbeds in sedimentary sections of probably volcanic origin are commonly called metabentonites or K-bentonites. As volcanic origin of Podolian clay interbeds is already proved, we prefer the term "volcanic beds".

\section{MATERIAL AND METHODS}

Fourteen drill core and two outcrop samples of volcanic beds from the Silurian of Podolia, Volynia, and Moldova were investigated (Figs. 1, 2). X-ray fluorescence (XRF) analyses, X-ray diffractometry, and wet chemical analyses were performed in the Institute of Geology at Tallinn Technical University.

The contents of $\mathrm{Nb}, \mathrm{Zr}, \mathrm{Y}, \mathrm{Th}, \mathrm{Ga}, \mathrm{Rb}, \mathrm{Sr}$, and $\mathrm{Ti}$ in samples, prepared as pressed powder pellets were measured at $25 \mathrm{~mA}$ and $45 \mathrm{kV}$, using the wave dispersive XRF spectrometer VRA-30 (VEB Freiberger Präzisionsmechanik). The X-ray tube with an Ag anode was used. The background was measured on both sides of the characteristic peaks. Sample matrix influence was equalized using peak/background intensity ratios in calibration. The precision of analyses ( \pm 2 standard deviations) was calculated from results of 10 replicate measurements: $\mathrm{Nb} \pm 2, \mathrm{Rb} \pm 2, \mathrm{Y} \pm 4, \mathrm{Th} \pm 6, \mathrm{Ga} \pm 4, \mathrm{Sr} \pm 4, \mathrm{Zr} \pm 10 \mathrm{ppm}$, and $\mathrm{TiO}_{2} \pm 0.06 \%$. Analyses were made in the same batch as 66 volcanogenic samples from the Upper Llandovery of Estonia and are therefore well comparable. Eight Estonian samples, analysed also in St. Andrews University (Scotland), 


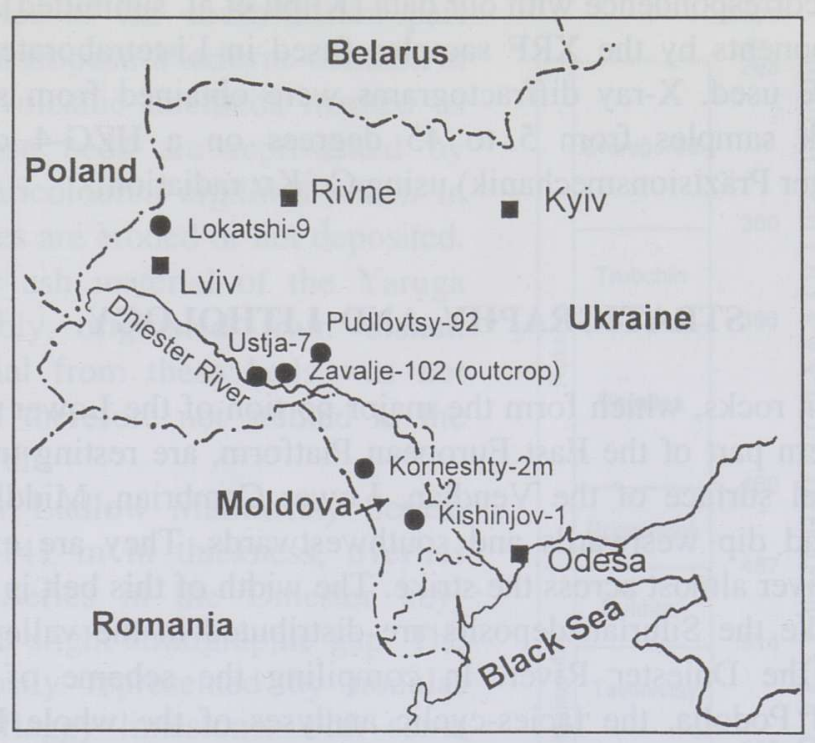

Fig. 1. Location of boreholes and outcrops.

\begin{tabular}{|c|c|c|c|c|}
\hline$\frac{\mathscr{\Phi}}{\omega}$ & 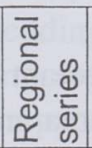 & Suite & Subsuite & $\begin{array}{l}\text { Studied } \\
\text { volcanic } \\
\text { interbeds }\end{array}$ \\
\hline \multirow{4}{*}{ 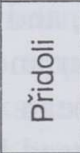 } & \multirow{4}{*}{ 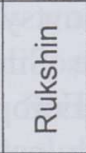 } & Zvenigorod & & \multirow{4}{*}{\begin{tabular}{|l} 
\\
$\mathrm{C}_{10}$ \\
$\mathrm{C}_{8}$ \\
$\mathrm{C}_{7}$ \\
$\mathrm{C}_{1,2,3,4,6}$
\end{tabular}} \\
\hline & & Trubchin & & \\
\hline & & Varnitsa & & \\
\hline & & Prigorodok & & \\
\hline \multirow{5}{*}{ 음 } & \multirow{4}{*}{ 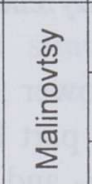 } & \multirow{2}{*}{ Rykhta } & Isakivtsy & \multirow{3}{*}{$\begin{array}{r}M_{11} \\
M_{9} \\
M_{8} \\
M_{5}\end{array}$} \\
\hline & & & Grinchuk & \\
\hline & & Tsviklivtsy & $\begin{array}{c}\text { Bernovo } \\
\text { Sokil }\end{array}$ & \\
\hline & & Konovka & Shutnovtsy & $-\mathrm{M}_{2}$ \\
\hline & \multirow{3}{*}{ 呬 } & Bagovitsa & & \\
\hline \multirow{2}{*}{$\begin{array}{l}\frac{1}{d} \\
\sum^{\prime}\end{array}$} & & Ternava & & \\
\hline & & Furmanovka & & \\
\hline \multirow{2}{*}{$\frac{1}{\frac{1}{0}}$} & \multirow{2}{*}{ 응 } & Step-Soch & & \multirow[t]{2}{*}{$-A_{1}$} \\
\hline & & Moroshesty & & \\
\hline
\end{tabular}

Fig. 2. Stratigraphic scheme of the Silurian of the southwestern part of the East European Platform with the position of the studied volcanic beds. 
showed good correspondence with our data (Kiipli et al. submitted). For analyses of main components by the XRF samples fused in Li-tetraborate (sample/flux ratio 1:5) were used. X-ray diffractograms were obtained from slurry mounts of whole rock samples from 5 to 45 degrees on a HZG-4 diffractometer (VEB Freiberger Präzisionsmechanik) using Co $\mathrm{K} \alpha$ radiation.

\section{STRATIGRAPHY AND LITHOLOGY}

The Silurian rocks, which form the major portion of the Lower Palaeozoic in the southwestern part of the East European Platform, are resting transgressively on an erosional surface of the Vendian, Lower Cambrian, Middle and Upper Ordovician, and dip westwards and southwestwards. They are exposed along the Dniester River almost across the strike. The width of this belt is about $80 \mathrm{~km}$. Along the strike the Silurian deposits are distributed in the valleys of the left tributaries of the Dniester River. In compiling the scheme of the Silurian stratigraphy of Podolia, the facies-cyclic analyses of the whole Dniester keysection has been used (Tsegelnjuk 1980a, 1980b). The lithostratigraphic units thus established reflect differences in palaeogeographic conditions of their formation. In this paper the correlation with the standard stratigraphic scheme is given according to Tsegelnjuk (1982) and Tsegelnjuk et al. (1983). It should be noted that the correlation of regional stratigraphy with the standard stratigraphic scheme is still under discussion and Huff et al. (2000) use a considerably different correlation.

Four regional series constituting the most important regional stratigraphic units have been established in the Dniester outcrop area and on the southwestern slope of the Ukrainian shield: Bolotyn, Yaruga, Malinovtsy, and Rukshin (Fig. 2). These series correspond to four big stages of the Silurian-Early Devonian sedimentation in the southwestern part of the East European Platform and are separated by discontinuities in sedimentation, partially caused by rearrangement of the regional structure.

The Bolotyn Series is $21-32 \mathrm{~m}$ thick. The lower part of the series is represented by marly nodular limestones, the upper part by dark grey or black argillites containing two interbeds of volcanic ash $-\mathrm{A}_{1}$ and $\mathrm{A}_{2}$ (indexes according to Tsegelnjuk 1980a, 1980b, 1983; Tsegelnjuk et al. 1983). In the regional stratigraphical scheme the Bolotyn Series correlates with the Telychian Stage of the Llandovery Series. Two graptolite biozones have been recorded: Monoclimacis griestoniensis and Monoclimacis crenulata.

The Yaruga Series is 101-121 m thick. The lower part of the section consists of marlstones and pelitomorphic limestones, the middle part of nodular limestones, and the upper part of marlstones and dolostones. The Yaruga Series is correlated with the Wenlock and lower Ludlow. In the outcrops of the Dniester area volcanic interbeds have not been found, but the deeper-water deposits from 
some boreholes of the southwestern part of the East European Platform contain at least 9 thin volcanic interbeds marked as $\mathrm{Y}_{1} \ldots \mathrm{Y}_{9}$. These beds are represented by micaceous varicoloured argillites which in most boreholes are eroded or not deposited. The volcanic ash material of the Yaruga Series possibly originated from distant areas. Material from these beds was not available and therefore not studied in the present research.

The upper Ludlow Malinovtsy Series, from 90 to $141 \mathrm{~m}$ in thickness, overlies the Yaruga Series in the Dniester keysection with a slight stratigraphic gap. The series is mostly represented by nodular and detrital flaggy limestone, with some stromatoporoid-coral-algal bioherms and flaggy dolomites in the uppermost part. The Malinovtsy Series contains 12 volcanic interbeds marked as $\mathrm{M}_{1} \ldots \mathrm{M}_{12}$.

The Rukshin Series (Prridoli-Lockhov), from 170 to $250 \mathrm{~m}$ in thickness, is represented by interbedding of dolomitic marlstones and flaggy micrograined massive dolomites in the lower part, and by black micritic, less commonly marly and nodular limestones in the upper part. The Silurian part of the Rukshin Series contains 11 volcanic interbeds marked as $\mathrm{C}_{1} \ldots \mathrm{C}_{11}$.

The lithology and stratigraphy of the Korneshty- $2 \mathrm{~m}$ section are represented in Fig. 3.

\section{MINERALOGY}

The most important mineralogical feature of the investigated clay beds, distinguishing them from the terrigenous shales, is the absence of terrigenous quartz as a main component and the coexistence, in different proportions, of illite or mixed-layer illite-smectite and potassium feldspar. Only traces of quartz, biotite, and apatite have been detected

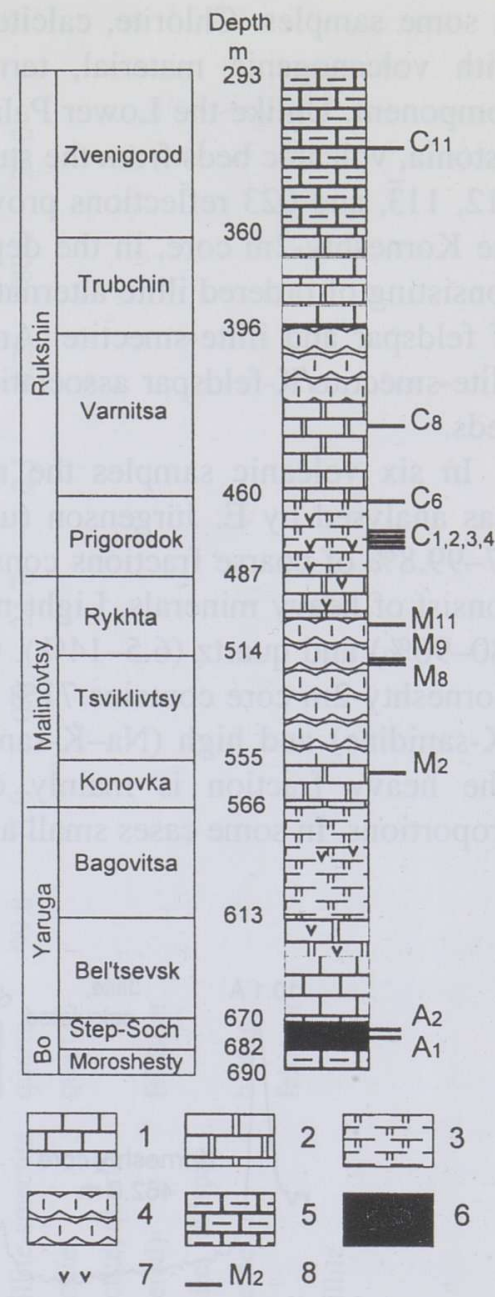

Fig. 3. Lithology and stratigraphy of the Silurian part of the Korneshty- $2 \mathrm{~m}$ section. 1, limestone; 2, dolostone; 3 , dolomitic marlstone; 4 , nodular limestone; 5 , argillaceous limestone; 6 , dark grey argillite; 7 , gypsum; 8 , altered volcanic ash interbeds. Thicknesses of beds (in cm): $\mathrm{A}_{1}-0.7, \mathrm{~A}_{2}-0.4, \mathrm{M}_{2}-15$, $M_{8}-15, M_{9}-10, M_{11}-14, C_{1}-3$, $\mathrm{C}_{2}-3, \mathrm{C}_{3}-7, \mathrm{C}_{4}-15, \mathrm{C}_{6}-50, \mathrm{C}_{8}-10$, $\mathrm{C}_{11}-5$. BO, Bolotyn Series. 
in some samples. Chlorite, calcite, and dolomite are usually absent. In contrast with volcanogenic material, terrigenous shales contain quartz as the main component. Unlike the Lower Palaeozoic volcanic beds and terrigenous rocks of Estonia, volcanic beds from the study area contain often illite with clear $11 \overline{1}, 11 \overline{2}$, $112,11 \overline{3}$, and 023 reflections proving stack ordering in the mineral structure. In the Korneshty- $2 \mathrm{~m}$ core, in the depth interval from 462 to $677 \mathrm{~m}$, volcanic beds consisting of ordered illite alternate with volcanic beds containing an association of feldspar and illite-smectite. An example of each is displayed in Fig. 4. The illite-smectite/K-feldspar association occurs frequently also in Estonian volcanic beds.

In six volcanic samples the mineralogical composition of coarse fractions was analysed by E. Jürgenson (unpublished, Table 1). The analyses show that 97-99.8\% of coarse fractions consist of light minerals and, accordingly, 0.2-3\% consist of heavy minerals. Light minerals are commonly represented by feldspar $(80-90 \%)$ and quartz (6.5-14\%). Only the sample from a depth of $677 \mathrm{~m}$ in the Korneshty- $2 \mathrm{~m}$ core contains $71 \%$ quartz in the light fraction. Feldspars with low (K-sanidine) and high (Na-K-sanidine) refractive indices can be distinguished. The heavy fraction is mainly composed of biotite and zircon in variable proportions. In some cases small amounts of apatite or garnet occur.

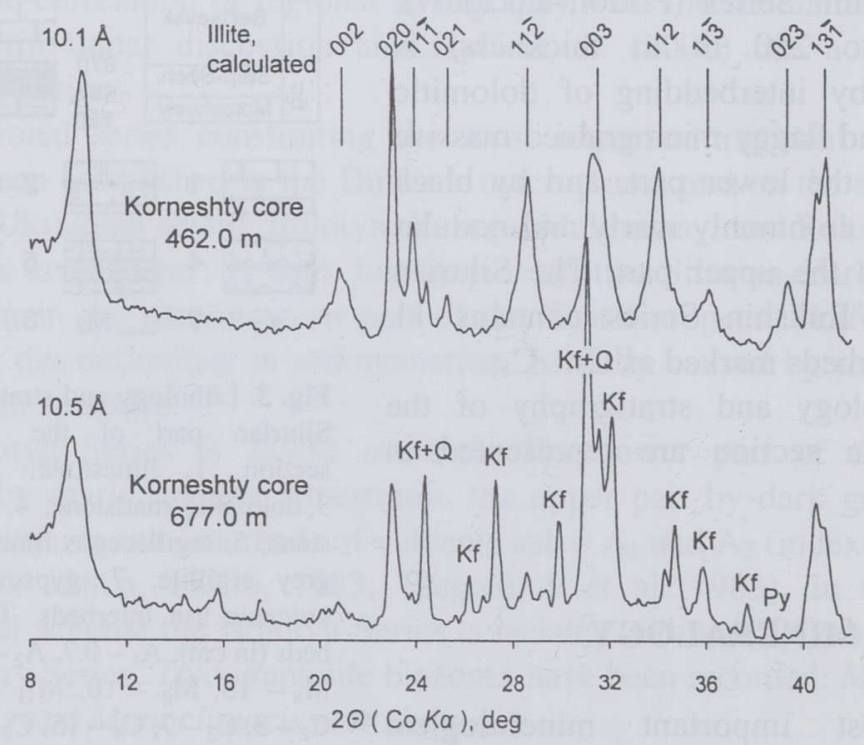

Fig. 4. X-ray diffractograms of bulk rock volcanic samples. Illite lines are calculated from the following unit cell parameters: $a-5.2 \AA, b-9.0 \AA, c-10.1 \AA$, and $\beta-101.26^{\circ}$. The upper diffractogram represents stack ordered illite and the lower an association of illite-smectite with K-feldspar (Kf). Q, quartz; Py, pyrite. 


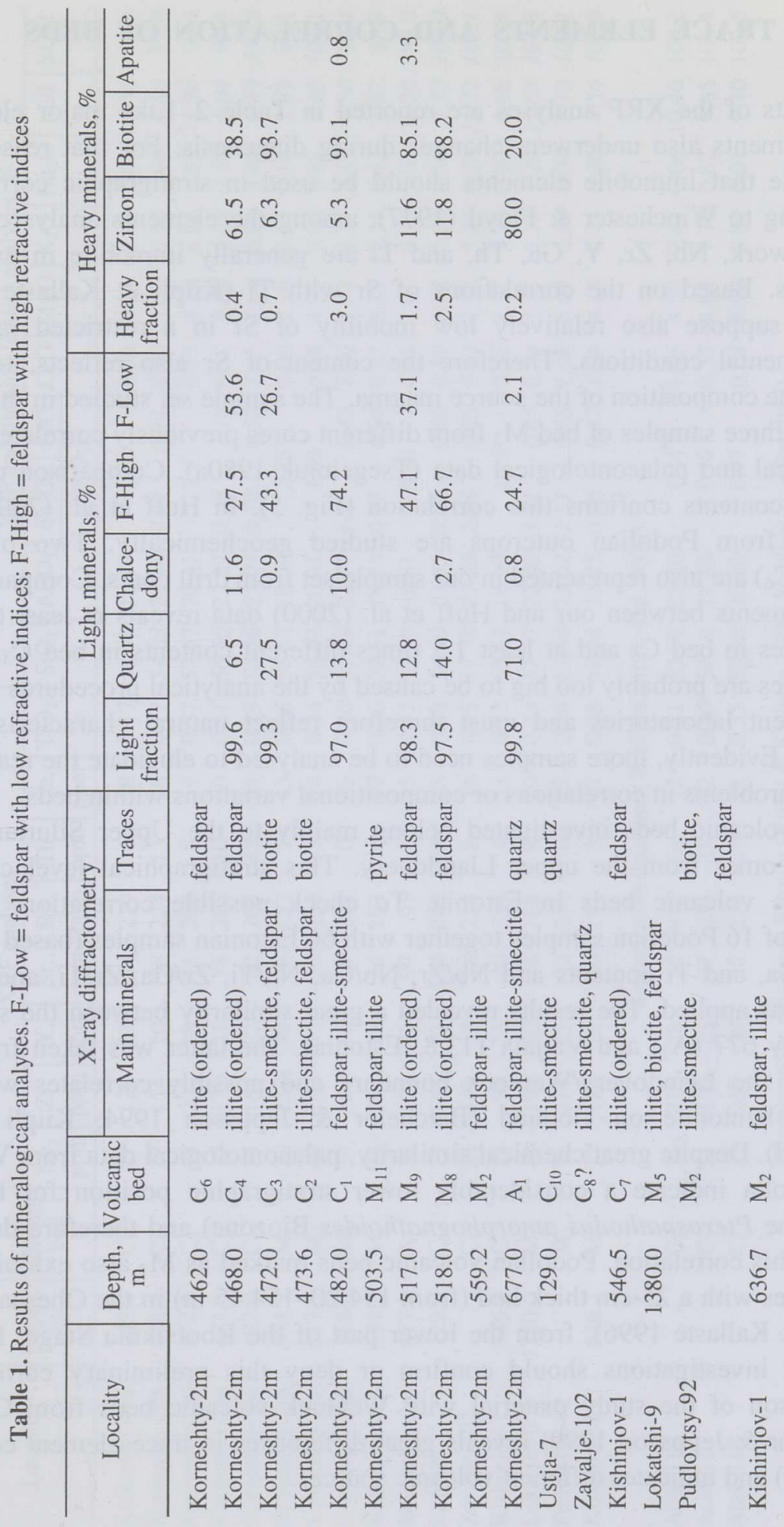




\section{TRACE ELEMENTS AND CORRELATION OF BEDS}

Results of the XRF analyses are reported in Table 2. Like major elements, trace elements also underwent changes during diagenesis. For that reason it is preferable that immobile elements should be used in stratigraphic correlation. According to Winchester \& Floyd (1977), among the elements analysed in the present work, $\mathrm{Nb}, \mathrm{Zr}, \mathrm{Y}, \mathrm{Ga}$, Th, and $\mathrm{Ti}$ are generally immobile in exogenic processes. Based on the correlations of $\mathrm{Sr}$ with Ti (Kiipli \& Kallaste 1996), we can suppose also relatively low mobility of $\mathrm{Sr}$ in a restricted range of environmental conditions. Therefore the content of $\mathrm{Sr}$ also reflects, to some extent, the composition of the source magma. The sample set studied in this work includes three samples of bed $\mathrm{M}_{2}$ from different cores previously correlated using lithological and palaeontological data (Tsegelnjuk 1980a). Comparison of trace element contents confirms this correlation (Fig. 5). In Huff et al. (2000) five samples from Podolian outcrops are studied geochemically. Two of them $\left(\mathrm{C}_{3}\right.$ and $\left.\mathrm{C}_{6}\right)$ are also represented in our sample set from drill cores. Comparison of trace elements between our and Huff et al. (2000) data reveals at least twofold differences in bed $\mathrm{C}_{6}$ and at least 1.5 times different contents in bed $\mathrm{C}_{3}$. These differences are probably too big to be caused by the analytical procedures applied in different laboratories and must therefore reflect natural characteristics of samples. Evidently, more samples need to be analysed to elucidate the real cause - either problems in correlations or compositional variations within beds.

The volcanic beds investigated belong mainly to the Upper Silurian; only bed $\mathrm{A}_{1}$ comes from the upper Llandovery. This stratigraphical level contains numerous volcanic beds in Estonia. To check possible correlation, cluster analysis of 16 Podolian samples together with 66 Estonian samples (based on $\mathrm{Nb}$, $\mathrm{Zr}, \mathrm{Sr}, \mathrm{Ga}$, and $\mathrm{Ti}$ contents and $\mathrm{Nb} / \mathrm{Zr}, \mathrm{Nb} / \mathrm{Ga}, \mathrm{Nb} / \mathrm{Ti}, \mathrm{Zr} / \mathrm{Ga}, \mathrm{Zr} / \mathrm{Ti}$, and $\mathrm{Ga} / \mathrm{Ti}$ ratios) was applied. The results revealed a great similarity between the samples Korneshty $677\left(\mathrm{~A}_{1}\right)$ and Valjala 113.8 (Estonia). The latter was taken from the bed near the Llandovery/Wenlock boundary and possibly correlates with the Ireviken bentonite on Gotland (Batchelor \& Jeppsson 1994; Kiipli et al. submitted). Despite great chemical similarity, palaeontological data from Volynia and Podolia indicate a considerably lower stratigraphic position for bed $A_{1}$ (below the Pterospathodus amorphognathoides Biozone) and therefore does not support this correlation. Podolian volcanic beds marked as $\mathrm{M}_{2}$ also exhibit some similarities with a $25-\mathrm{cm}$ thick bed (from 154.20-154.45 m) in the Ohesaare core (Kiipli \& Kallaste 1996), from the lower part of the Rootsiküla Stage. Further chemical investigations should confirm or deny this preliminary correlation. Comparison of the study material with Wenlock volcanic beds from Gotland (Batchelor \& Jeppsson 1999) reveals great differences in trace element contents $\left(\mathrm{TiO}_{2}, \mathrm{Zr}\right)$ and indicates different volcanic sources. 


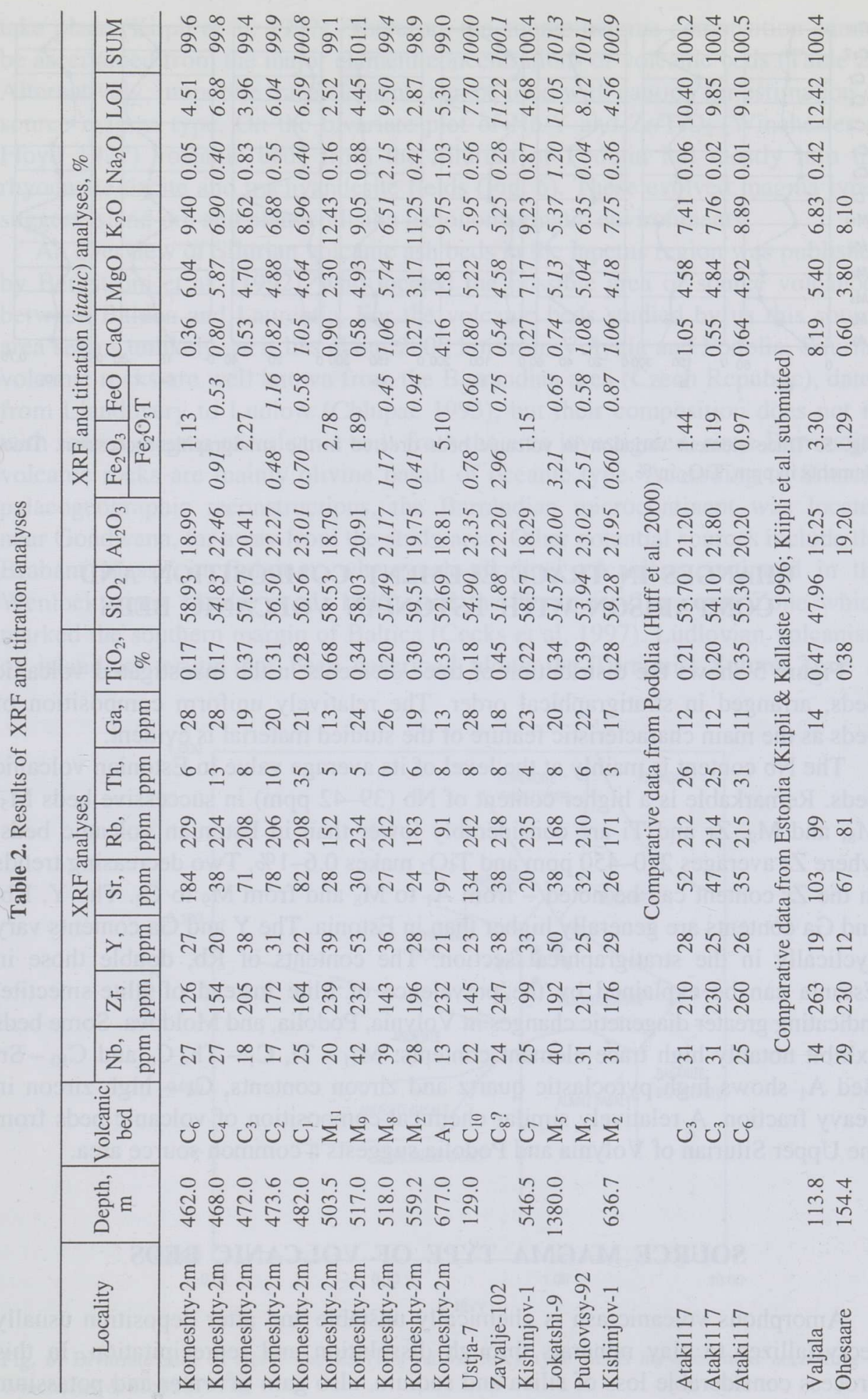



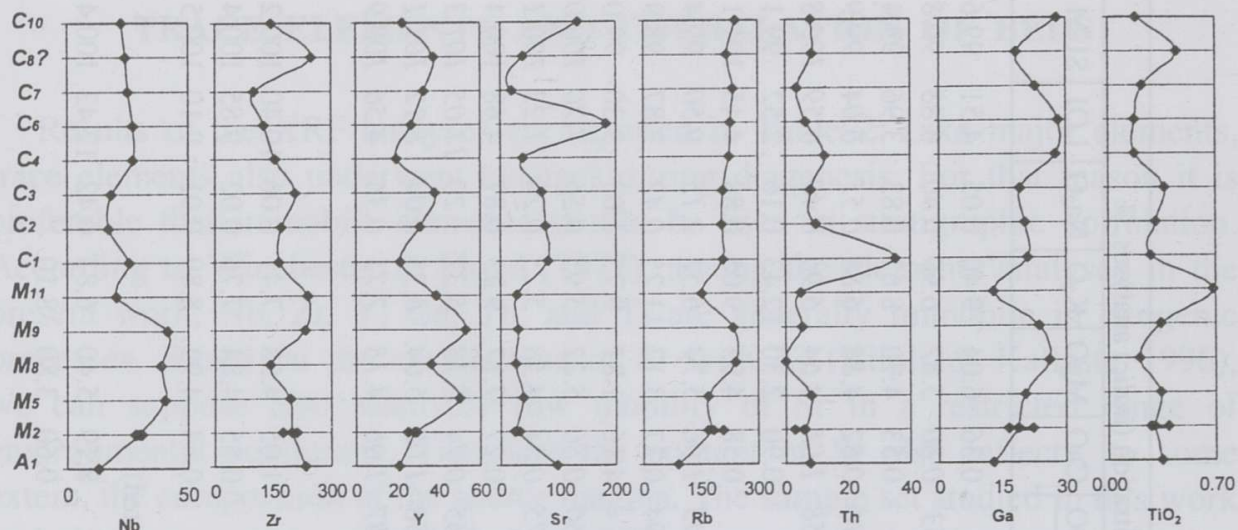

Fig. 5. Trace element variation in volcanic beds ordered in the stratigraphic succession. Trace elements in $\mathrm{ppm}, \mathrm{TiO}_{2}$ in $\%$.

\section{CHANGES IN TRACE ELEMENT COMPOSITION AND COMPARISON WITH ESTONIAN VOLCANIC BEDS}

Figure 5 shows the distribution of trace elements in the investigated volcanic beds, arranged in stratigraphical order. The relatively uniform composition of beds as the main characteristic feature of the studied material is evident.

The $\mathrm{Nb}$ content is mainly at the level of its average value in Estonian volcanic beds. Remarkable is a higher content of $\mathrm{Nb}(39-42 \mathrm{ppm})$ in successive beds $\mathrm{M}_{5}$, $\mathrm{M}_{8}$, and $\mathrm{M}_{9} . \mathrm{Zr}$ and $\mathrm{Ti}$ are considerably lower than in Estonian volcanic beds, where $\mathrm{Zr}$ averages $270-450 \mathrm{ppm}$ and $\mathrm{TiO}_{2}$ makes $0.6-1 \%$. Two decreasing trends in the $\mathrm{Zr}$ content can be noted - from $A_{1}$ to $M_{8}$ and from $M_{9}$ to $C_{7}$. The $Y, R b$, and $\mathrm{Ga}$ contents are generally higher than in Estonia. The $\mathrm{Y}$ and $\mathrm{Ga}$ contents vary cyclically in the stratigraphical section. The contents of $\mathrm{Rb}$, double those in Estonia can be explained by the prevalence of illite instead of illite-smectite, indicating greater diagenetic changes in Volynia, Podolia, and Moldova. Some beds exhibit notably high trace element contents: $\mathrm{M}_{11}-\mathrm{Ti}, \mathrm{C}_{1}-\mathrm{Th}, \mathrm{C}_{6}$ and $\mathrm{C}_{10}-\mathrm{Sr}$. Bed $\mathrm{A}_{1}$ shows high pyroclastic quartz and zircon contents, $\mathrm{C}_{4}$ - high zircon in heavy fraction. A relatively similar chemical composition of volcanic beds from the Upper Silurian of Volynia and Podolia suggests a common source area.

\section{SOURCE MAGMA TYPE OF VOLCANIC BEDS}

Amorphous volcanic ash is chemically unstable and after deposition usually recrystallizes to clay minerals through dissolution and reprecipitation. In this process considerable loss of silica and sodium, also gain of water and potassium 
take place (Kiipli et al. 1997). Therefore the source magma composition cannot be ascertained from the major element concentrations of volcanic beds (Table 2). Alternatively, immobile trace elements can be used with caution for estimation of source magma type. On the bivariate plot of $\mathrm{Nb} / \mathrm{Y}$ and $\mathrm{Zr} / \mathrm{TiO}_{2}$ (Winchester \& Floyd 1977) volcanic beds from the Silurian of Podolia fall mostly into the rhyodacite-dacite and trachyandesite fields (Fig. 6). These evolved magma types suggest island-arc and plate collision tectonomagmatic environments.

An overview of Silurian volcanic ash beds in the Iapetus region was published by Bergström et al. (1992), who located the possible area of source volcanoes between Baltica and Laurentia. For the volcanic beds studied by us this source area seems unlikely, as it lies about $2000 \mathrm{~km}$ from Volynia and Podolia. Silurian volcanic rocks are well known from the Barrandian area (Czech Republic), dated from Llandovery to Ludlow (Chlupač 1993), but their composition does not fit with source magma of volcanic beds from the area investigated, since Barrandian volcanic rocks are mainly olivine basalt of oceanic type. According to Silurian palaeogeographic reconstructions, the Barrandian microcontinent was located near Gondwana, far away from the study area. Other potential sources include the Brabant Massif in Belgium, where calc-alkaline volcanism continued in the Wenlock times (Andre et al. 1986), and the Tornquist-Teysseyre Zone which marked the southern margin of Baltica (Cocks et al. 1997). Ludlovian volcanism of island-arc origin has been described along the Tornquist Suture Zone at

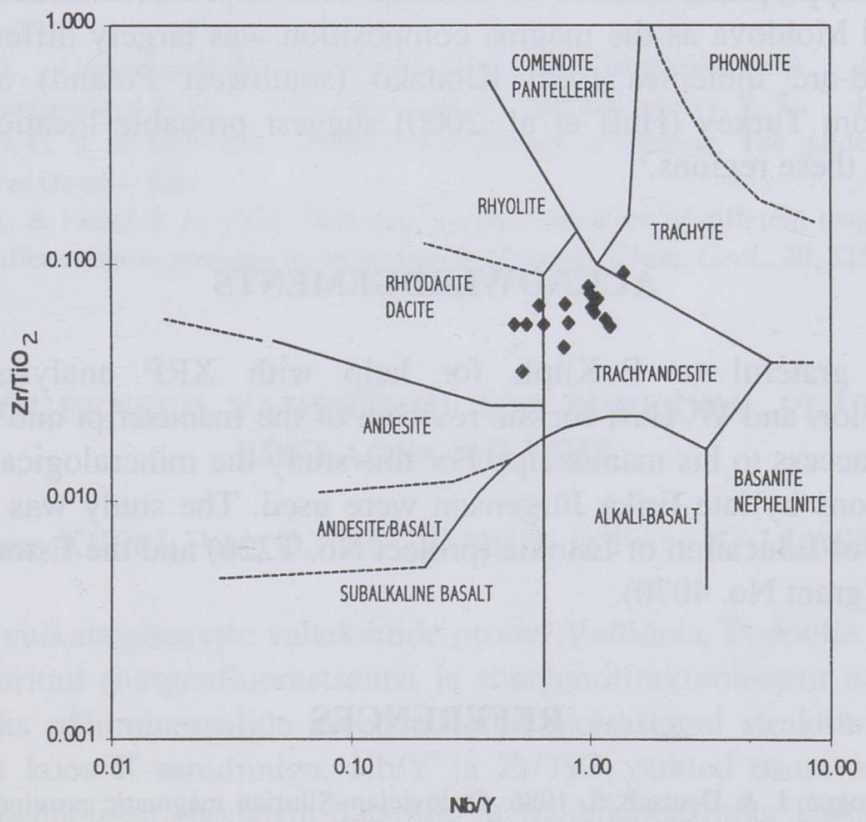

Fig. 6. Bivariate plot of $\mathrm{Nb} / \mathrm{Y}$ and $\mathrm{Zr} / \mathrm{TiO}_{2}$ ratios. Rock type fields are presented according to Winchester \& Floyd (1977). 
Klodzko in Poland (Oliver et al. 1993). In Silurian times the Tornquist Sea had almost closed, constituting a narrow marginal sea of the Rheic Ocean. The area near the Tornquist Suture Zone, marking the southwest border of the East European Platform, is the probable region of source volcanoes of the studied volcanic beds, although Huff et al. (2000) suggest that the source volcanoes may have been located in the Rheic Ocean (Turkey).

\section{CONCLUSIONS}

1. X-ray diffractometry revealed two associations of main minerals in volcanic beds from the Silurian of Podolia, Volynia, and Moldova: (1) domination of illite with stack ordering and (2) association of illite-smectite with K-sanidine.

2. Trace element composition does not contradict the correlation of bed $\mathrm{M}_{2}$ in three cores: Korneshty-2m, Kishinjov-1, and Pudlovtsy-92. Further geochemical and mineralogical investigations are needed to check former correlations of volcanic beds.

3. $\mathrm{Nb} / \mathrm{Y}$ and $\mathrm{Zr} / \mathrm{TiO}_{2}$ ratios suggest the source magma composition was rhyodacite-dacite and trachyandesite, indicating island-arc and plate collision volcanism.

4. The relative similarity in chemical composition of the Upper Silurian volcanic beds suggests a common source area. Volcanoes from the Barrandian area are not appropriate sources of volcanic beds from the Silurian of Volynia, Podolia, and Moldova as the magma composition was largely different in these areas. Island-arc tholeiites from Klodzko (southwest Poland) and Silurian volcanics from Turkey (Huff et al. 2000) suggest probable location of source volcanoes in these regions.

\section{ACKNOWLEDGEMENTS}

We are grateful to E. Kiipli for help with XRF analysis, D. Kaljo, R. A. Batchelor, and W. Huff for the revision of the manuscript and W. Huff for allowing us access to his manuscript. For this study the mineralogical analysis of coarse fractions by late Erika Jürgenson were used. The study was financed by the Ministry of Education of Estonia (project No. T226) and the Estonian Science Foundation (grant No. 4070).

\section{REFERENCES}

Andre, L., Hertogen, J. \& Deutsch, S. 1986. Ordovician-Silurian magmatic provinces in Belgium and the Caledonian Orogeny in middle Europe. Geology, 14, 879-882.

Batchelor, R. A. \& Jeppsson, L. 1994. Late Llandovery bentonites from Gotland, Sweden, as chemostratigraphic markers. J. Geol. Soc. London, 151, 741-746. 
Batchelor, R. A. \& Jeppsson, L. 1999. Wenlock metabentonites from Gotland, Sweden: geochemistry sources and potential as chemostratigraphic markers. Geol. Mag., 136, 661-669.

Bergström, S. M., Huff, W. D., Kolata, D. R. \& Kaljo, D. 1992. Silurian K-bentonites in the Iapetus Region: a preliminary event stratigraphic and tectonomagmatic assessment. Geol. Fören. Stockholm Förhandl., 114, 327-334.

Chlupač, I. 1993. Silurian. In Geology of the Barrandian: A Field Trip Guide, pp. 16-18. Waldemar Kramer, Frankfurt am Main.

Cocks, L. R. M., McKerrow, W. S. \& van Stall, C. R. 1997. The margins of Avalonia. Geol. Mag., 134, 627-636.

Huff, W. D., Bergström, S. M. \& Kolata, D. R. 2000. Silurian K-bentonites of the Dnestr Basin, Podolia, Ukraine. J. Geol. Soc. London, 157, 493-504.

Kiipli, E. \& Kallaste, T. 1996. Geochemical characterization of some Estonian metabentonites. Proc. Estonian Acad. Sci. Geol., 45, 68-77.

Kiipli, T., Kiipli, E. \& Kallaste, T. 1997. Metabentonite composition related to sedimentary facies in the Lower Silurian of Estonia. Proc. Estonian Acad. Sci. Geol., 46, 93-104.

Kiipli, T., Männik, P., Batchelor, R. A., Kiipli, E., Kallaste, T. \& Perens, H. Correlation of Telychian (Silurian) metabentonites in the Baltic region. Norsk Geol. Tiddskr. (submitted).

Oliver, G. J. H., Corfu, F. \& Krogh, T. E. 1993. U-Pb ages from SW Poland: evidence for a Caledonian suture between Baltica and Gondwana. J. Geol. Soc. London, 150, 355-369.

Savchenko, N. A. \& Krandievskij, V. S. 1967. About Silurian volcanism in the Pripjat region, Volyno-Podolia and adjacent areas. Dokl. Akad. Nauk SSSR, 172, 172-173 (in Russian).

Tsegelnjuk, P. D. 1980a. Rukshin and Tsygan series (Upper Silurian-Lower Devonian) of Podolia and Volynia. Preprint 80-2, Inst. geol. nauk, Kiev (in Russian).

Tsegelnjuk, P. D. 1980b. Yaruga and Malinovtsy series (Lower-Upper Silurian) of Podolia and Volynia. Preprint 80-11, Inst. geol. nauk, Kiev (in Russian).

Tsegelnjuk, P. D. 1982. Silurian Chitinozoans of Podolia. Naukova Dumka, Kiev (in Russian).

Tsegelnjuk, P. D. 1983. Ulichk Series of the Silurian. Preprint 83-1, Inst. geol. nauk, Kiev (in Russian).

Tsegelnjuk, P. D., Gritsenko, V. P., Konstantinenko, L. I., Ishchenko, A. A., Abushik, A. F., Bogoyavlenskaya, O. V., $\quad$ Drygant, D. M., Zaika-Novatsky, V. S., $\quad$ Kadlets, N. M., Kiselev, G. N. \& Sytova, V. A. 1983. The Silurian of Podolia. The guide to excursion. Naukova Dumka, Kiev.

Winchester, J. A. \& Floyd, P. A. 1977. Geochemical discrimination of different magma series and their differentiation products using immobile elements. Chem. Geol., 20, 325-343.

\title{
VULKANOGEENSED VAHEKIHID IDA-EUROOPA PLATVORMI EDELAOSA SILURIS
}

\author{
Tarmo KIIPLI, Petro D. TSEGELNJUK ja Toivo KALLASTE
}

Kuutteist vulkanogeensete vahekihtide proovi Volõõnia, Podoolia ja Moldova silurist on uuritud röntgenfluorestsentsi ja röntgendifraktomeetria meetodil. On avastatud kaks põhimineraalide assotsiatsiooni: korrastatud struktuuriga illiit ja illiit-smektiit koos $\mathrm{K}$-sanidiiniga. $\mathrm{Nb} / \mathrm{Y}$ ja $\mathrm{Zr} / \mathrm{TiO}_{2}$ suhted osutavad, et lähtemagma oli tõenäoliselt rüodatsiit-datsiitne ja trahhüandesiitne. Üsna ühetaoline mikroelementide sisaldus vulkanogeensetes kihtides osutab hilissiluriaegsete vulkaanipursete samale lähtealale. 


\section{ВУЛКАНОГЕННЫЕ ПРОСЛОИ В СИЛУРЕ ЮГО-ВОСТОЧНОЙ ЧАСТИ ВОСТОЧНО-ЕВРОПЕЙСКОЙ ПЛАТФОРМЫ}

Тармо КИЙПЛИ, Петро Д. ЦЕГЕЛЬНЮК и Тойво КАЛЛАСТЕ

Изучено 16 образцов из вулканогенных прослоев силура Волыни, Подолии и Молдовы методами рентгенофлуоресцентного и рентгенодифрактометрического анализа. В вулканогенных прослоях установлены две ассоциации основных минералов: 1) иллит с упорядоченной структурой и 2) иллит-смектит с калиевым санидином. Отношения $\mathrm{Nb} / \mathrm{Y}$ и $\mathrm{Zr} / \mathrm{TiO}_{2}$ позволяют предполагать риодацит-дацитовый и трахандезитовый состав исходной магмы. Относительно однообразный микроэлементный состав указывает на общее расположение вулканов. 